\title{
Sustainable and unsustainable agriculture in Ghana and Nigeria: 1960-2009
}

\author{
S. Onyeiwu, E. Pallant \& M. Hanlon \\ Departments of Economics, Environmental Science, \\ and Biology (respectively), Allegheny College, USA
}

\begin{abstract}
The agricultural sector of African economies has faced considerable challenges within the past 50 years or so. Although agricultural production on the continent rose by an annual average of $2 \%$ between 1965 and 1980 and has continued to increase by $1.8 \%$ annually since then, population growth of $2.9 \%$ per year has resulted in a per capita decline in agricultural production. From self-sufficiency in food production before the 1960s, many African countries have become net food importers, with a handful of them facing severe food shortages arising from drought, desertification, climate change and wars. In this paper we use the case of Ghana and Nigeria to explore some of the salient dynamics that have resulted in the current crisis in the agricultural sector of African economies. We argue that soil conditions, climate change, and population growth, in combination with ineffective economic policies, have contributed immensely to the sordid state of agriculture in Africa. We use historical and contemporary evidence gathered from Ghana and Nigeria during several visits to show how economic policies have interacted with biophysical and environmental factors to generate an unsustainable use of land, agricultural labor, and natural resources.
\end{abstract}

Keywords: Ghana, Nigeria, sustainable agriculture, climate, structural adjustment, environmental economics, sustainable development, Sub-Saharan Africa.

\section{Introduction}

Most analysts agree that African agriculture has been on an unsustainable path for the past five decades or so; however, there is no consensus on the factors responsible for this unsustainability [1-3]. Explanations of the causes of the 
agrarian crisis in Africa have tended to be monocausal in nature, focusing on single factors like the so-called irrationality of African farmers [4], anachronistic land tenure systems/social structures $[5,6]$ and ineffective economic policies that generate perverse incentives for agricultural development [7]. Monocausal explanations have limited our understanding of the dynamics of African agriculture for of a number of reasons. First, they are too narrow in the sense that they ignore several factors that affect sustainable agriculture. Second, they seem to be Eurocentric by examining African agriculture on the basis of assumptions relevant to Western economies and society [8, 9]. Third, they gloss over the interconnectedness of economic and biophysical feedback loops between the various factors affecting African agriculture.

We believe a more useful approach for understanding African agriculture is an integrated methodology that explores the role of multiple factors that interact in mutually reinforcing ways. In this paper, we seek to provide a historical, biophysical, and socio-economic context for why African agriculture has become unsustainable. Evidence gathered from our visits to Ghana and Nigeria between 2001 and 2008, as well as reports by the World Bank and the FAO, are used to support our analysis.

One common thread in the conventional definition of agricultural sustainability is the notion that sustainable agriculture is a system that "makes the best use of nature's goods and services whilst not damaging the environment" [10]. In other words, sustainable agriculture enhances the "productive values of natural, social and human capital" [11].

\section{Transformation of agriculture in Ghana and Nigeria: 1960-2009}

\subsection{Environment}

Through direct observation and evaluation of available data we have measured trends in precipitation, soil fertility and fertilizer use, forest cover, and agricultural practices. World Bank Country Environmental Analyses discovered that the cost of environmental degradation, due to both biophysical and anthropogenic factors, totalled $10 \%$ of the GDP of Ghana and $9 \%$ of Nigeria's.

\subsubsection{Precipitation}

Rainfall patterns in both Ghana and Nigeria have been shifting over the past fifty years. The Ghanaian EPA estimates that rainfall for all of Ghana has been decreasing by $2.4 \%$ per decade since 1960 [12] and is predicted to decline another $10 \%$ by 2050 according to the IPCC. Similarly, the length of the rainy season in North East Nigeria has been decreasing since 1961, as has the total amount of rainfall received [13]. In the northern regions of both countries rainfall is already becoming more sporadic, intense, and less reliable [14-16]. These regions are at threat for desertification, which is already occurring in the northernmost regions of Nigeria [17]. 
On repeated visits to Ghana and Nigeria long-term residents told us that the beginning of the rainy season was delayed and shorter in overall duration. Additionally, farmers described rainfall as being more intense, causing greater runoff, flooding, and erosion, as well as lower rates of infiltration. Rainfall intensity is important to farmers because it can dictate success or failure of crops, whereas total rainfall gathered in collectors might not reflect this impact.

\subsubsection{Forests}

Multiple factors have led to the increasing rate of deforestation in Ghana and Nigeria. When Ghana received independence in 1957, forest cover measured 8.2 million hectares. In the time since, deforestation has progressed at an annual average of 65,000 hectares lost per year, leaving only 1.6 million hectares of forest cover [18] (Figure 1). Ninety-five percent of Ghana's high forest has already been logged and only $1 \%$ of what is left is within protected areas such as wildlife sanctuaries, game reserves, and sacred groves [19].

In Nigeria, areas dominated by guinea vegetation (trees, woodlands, and shrubs) decreased by $50 \%$ during the same period, with the majority of the area converting to agricultural use in the 1990s. Between 1986 and 1990, forest area declined by 3.1 million hectares and between 1990 and 1995, the amount of covered area declined by an additional 3.3 million hectares [20].

Causes of deforestation include increasing population, resulting in shorter rotations of slash and burn agriculture and increased demands for charcoal production. Several rural communities in Ghana are cutting down trees for processing into charcoal, which has become a source of income for cash-strapped rural dwellers (See section on Economy for further discussion of charcoal processing). Village women describe having to walk increasingly long distances - sometimes 12 hours - to gather sufficient fuelwood for home use.

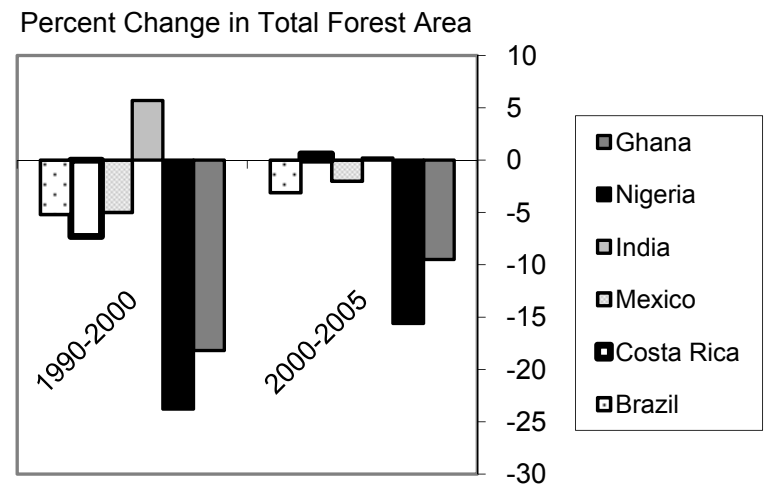

Figure 1: Deforestation in Ghana and Nigeria as compared to other, nonAfrican nations.

\subsubsection{Soil quality}

Declining soil fertility is considered to be the major constraint to agricultural production even though more land is under cultivation [21, 22]. The Global 
Assessment of Human Induced Soil Degradation (GLASOD) survey done in 1990 found $69 \%$ and $27 \%$ of the soils in Ghana and Nigeria, respectively, to be degraded due to, in large part, unsustainable farming practices and deforestation [23]. None of the soils found in Nigeria are conducive to productive agriculture, and many are considered the worst [17], putting farmers at an immediate disadvantage. These soils lack proper drainage and water retention, nutrient composition, and structure to allow proper root growth. As a result of population increase, pressure on land has reduced the 8-15 years natural fallow period that is required to regenerate soil fertility after 1-3 years of cropping to only 2-3 years, further reducing soil fertility $[21,22]$. Soils are not adequately protected by cover crops as crop rotation is hardly practiced, resulting in fragile soils that are easily eroded, a problem exacerbated by overfarming and overgrazing. Sporadic and intense rainfalls add to these issues by inducing erosion [24, 25].

Almost all the nutrient balances in Ghana show a deficit as more nutrients are removed by harvesting or lost to erosion than are applied as fertilizers [21, 22]. This represents a loss of potential yield and progressive soil impoverishment. According to FAO estimates, cassava and yams account for almost $20 \%$ of the cropped area, but $37 \%$ of the nitrogen deficit. The highest depletion rates are in the southeast and the central west parts of Ghana, which correspond to the cassava area [26].

These nitrogen deficiencies, though, are not overcome with fertilizer application as is the case in the developed world. The application of fertilizers to soils throughout Ghana is very low, as fertilizer use has been on the decline instead of increasing as the cropped area expands. In the 1980s fertilizer imports were reduced and subsidies removed, resulting in the price being too high for most farmers (See discussion below regarding impact of structural adjustment programs of the 1980s). Fertilizer use declined from $21.9 \mathrm{~kg}$ of fertilizer material per hectare arable land in 1978 to $7.3 \mathrm{~kg} / \mathrm{ha}$ in 1993 .

\subsection{Economy}

Following the United Nations' declaration of the 1960s as the "First Development Decade" for developing countries, several Sub-Saharan African (SSA) countries achieved impressive growth rates that averaged 6-8\% per annum. More encouraging, perhaps, is the fact that these growth rates were accompanied by a robust agricultural sector that proved to be sustainable from the economics standpoint. The agricultural sector was not only the mainstay of the Ghanaian and Nigerian economies in the 1960s, it did so without posing serious threats to these countries' ecosystems. In Nigeria agricultural exports represented about $85 \%$ of total exports in the 1960 s, and contributed $60 \%$ of the GDP [27], though about three-quarters of the country's land area was under cultivation. Subsistence agriculture in both Ghana and Nigeria was based largely on the time-tested methods of shifting cultivation, crop rotation, and organic farming, without extensive use of fertilizers.

Things began to take a dramatic turn, however, in the 1970s. Agriculture's role in the Ghanaian and Nigerian economies not only began to falter, but also glided into a new trajectory that proved to be unsustainable. While agricultural 
value added began to decline in the 1970s, agricultural land and the area devoted to farming were on the rise - a phenomenon that signalled the onset of declining productivity in the sector. Agricultural land as a percentage of land area in Ghana rose from $51 \%$ in the late 1960 s to $65 \%$ in 2005 . Arable land as a percentage of land area also increased from $7 \%$ in 1969 to $18 \%$ in 2005 . There were similar changes in land use in Nigeria, but they were not as dramatic as those of Ghana. For instance, agricultural land as a percentage of land area rose from $77 \%$ in 1969 to $81 \%$ in 2005 , while arable land as a percentage of land area increased from $30 \%$ to $35 \%$ within the same period.

Despite increases in agricultural and arable land, agricultural value added as a percentage of GDP in Ghana dropped from 46\% in 1969 to 37\% in 2005. Although data on agricultural value added in Nigeria during the 1960s to $1990 \mathrm{~s}$ are not available, data for the 2000s suggest a downward trend. Agricultural value added as a percentage of GDP fell from $40 \%$ in 2002 to $33 \%$ in 2005 , while arable land per person dropped from 1 hectare to zero implying a scarcity of land for agricultural production.

\subsection{Equity}

Per capita income levels in Ghana and Nigeria today are not significantly different from what they were in the 1960s. Indeed, it is now believed that many Ghanaians and Nigerians enjoyed higher living standards in the 1960s than they did in the 1990s [28]. Contrary to the 1960s, Ghanaians and Nigerians are increasingly dependent on food imports to meet growing shortfalls in domestic food supply. As subsistence agriculture has not been able to generate sufficient income for rural farmers, more and more people have begun to migrate to urban areas in both Ghana and Nigeria. In $196176 \%$ of the Ghanaian population and

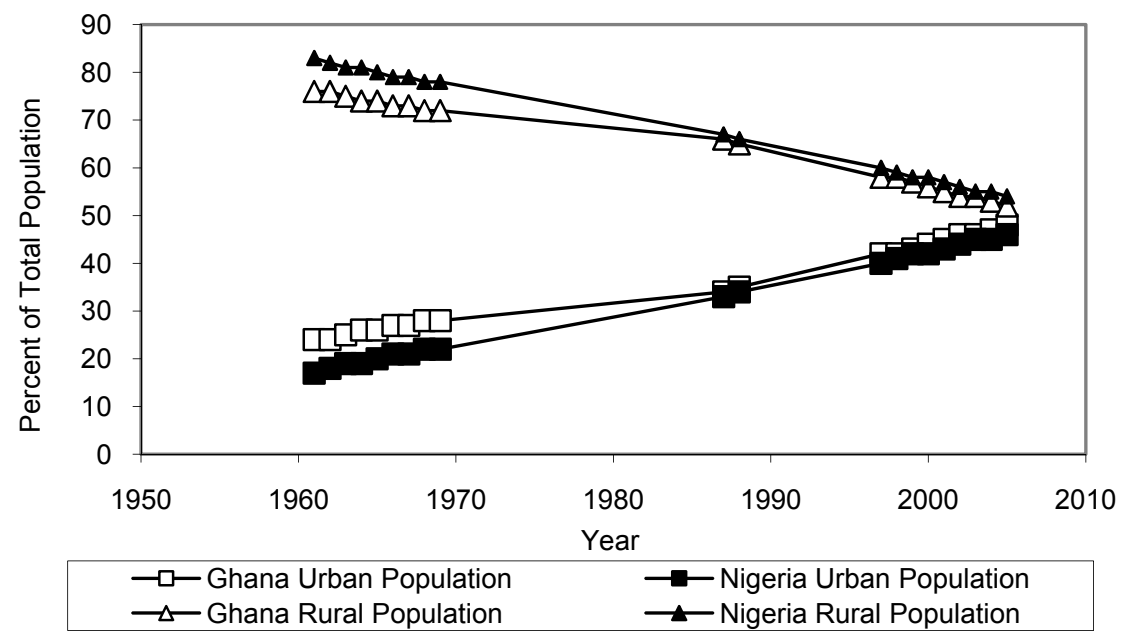

Figure 2: Rural and urban populations as a percentage of the total population in Ghana and Nigeria. 
$83 \%$ of the Nigerian population lived in rural areas. By 2005, these numbers had dropped drastically, to $52 \%$ for Ghana and $54 \%$ for Nigeria (Figure 2). Furthermore, of those living in urban areas in Ghana and Nigeria, 70\% and 79\%, respectively, were living in slums, as designated by the United Nations Human Settlements Program (UN-HABITAT).

Many analysts believe that agriculture has become unsustainable in Ghana and Nigeria because of the introduction of economic and industrial policies that are incompatible with sustainable agriculture. One of these policies is structural adjustment programs, which ostensibly were supposed to revive African economies, but have had the backwash effects of undermining the agricultural sector. We discuss the effects of structural adjustment programs in the next section.

\subsection{Structural adjustment and sustainable agriculture in Ghana and Nigeria}

The Lewisian assumption that Import-Substitution Industrialization (ISI) would promote industrial development and draw surplus labor away from the agricultural sector became illusory after two decades of its implementation in Ghana and Nigeria. In fact, Africa appears to have had the worst of two worlds: a world in which agriculture has become more unsustainable, and another in which the continent's industrial performance has been abysmal.

By the early 1980s, a decade aptly characterized as a "lost decade" for Africa, it became obvious that the continent was sliding over a dangerous economic cliff. To prevent deterioration in their economies, and upon the urging of the World Bank and the IMF, many African countries implemented neoliberal economic policies or Structural Adjustment Programs (SAP) in the 1980s. The introduction of SAP was expected to not only reverse this inglorious industrial development trajectory, but also to set African enterprises on a new path of efficiency, higher productivity, and international competitiveness. SAP is premised on the notion that once African countries get "their prices right" through trade liberalization, devaluation, privatization, removal of government subsidies, and reduction or elimination of budget deficits, firms will respond by reducing inefficiency, eliminating wastes, and raising total-factor productivity.

SAP is predicated on the same assumption of the Lewis model: the notion that industrial development is the key for transforming the rural sector. In addition to promoting industrial development SAP also introduced explicit policies (mainly price incentives) for strengthening the agricultural sector. A key component of structural adjustment is the removal of price controls and the abolition of marketing boards that had for many years monopolized the buying and selling of primary products. Structural adjustment and the removal of price controls were expected to boost farmers' incomes. With the attractiveness of agricultural production under SAP, farmers are expected to invest in land acquisition and improvement. In some cases, marginal land may be brought under cultivation.

Rather than promote agricultural development, SAP has exacerbated some of the problems created by ISI. One of those problems is rural-urban migration, which has now taken a new dimension. Following the liberalization of product 
markets under SAP, the prices of goods and services have increased significantly in both Ghana and Nigeria. For instance, the consumer price index for all items in rural areas more than doubled from 482.3 (with 1975 as a base year) in 1985, a year before SAP was introduced in Nigeria, to 1,194.6 in 1989 [29]. Rural dwellers are also now required to pay user fees for social services previously provided free-of-charge by the government, or heavily subsidized. This means that farmers have to generate additional income to cope with the increase in the cost of living. Unable to cope with the escalation in the cost of living, many young rural dwellers are migrating to urban areas to explore better job opportunities. Our visits to villages in Ghana and Nigeria show that a preponderance of rural dwellers are mainly older men and women who, by virtue of old age, are unable to migrate. They are also too frail to work long hours on the farm, thus leading to a reduction in agricultural productivity.

Following a review of rural household surveys in a number of African countries, Bryceson [3] concludes that neo-liberalism (or SAP) has exacerbated poverty in rural Africa by weakening the continent's "agrarian foundation" and by accelerating the pace of "deagrarianisation and depeasantisation" of the region. According to Bryceson [3], the removal of subsidies for agricultural inputs and social programs such as health and education, has forced rural farmers to diversify their income sources. This attempt at diversification has resulted in a shift of resources to non-agricultural activities, thus undermining agricultural production-which structural adjustment ostensibly strives to promote.

Several rural communities in Ghana appear to be coping with the escalation in the cost of living by resorting to unsustainable use of natural resources. Specifically, they are cutting down trees for processing into charcoal, which has become a source of income for cash-strapped rural dwellers. It is not uncommon to find hundreds of bags of charcoal along the Kumasi-Tamale highway, waiting to be transported onward to Accra, Cape Coast and other cities in Ghana. It is estimated that structural adjustment in Ghana caused a 4\% loss in GDP just due to environmental degradation [24]. Agriculture imposed the greatest environmental costs, at $6.9 \%$ of the total or 28.8 billion cedis (U.S. $\$ 88.5$ million). These costs were reflected in wind and water erosion, soil compaction, surface soil crusting and loss of soil stability and fertility, nor forgetting the indiscriminate use of fertilizers and pesticides. While these unsustainable agricultural practices had adverse effects on the environment, they also intensified the poor living conditions of a majority of Ghanaians and Nigerians [19]. In the next section, we discuss the impact of unsustainable agriculture on living conditions in a small village in Nigeria.

\section{The Village of Umuluwe, Southeast Nigeria as an example of unsustainability}

To really understand the impact of failing sustainability of agriculture on widening the equity gap for rural dwellers in Ghana and Nigeria we describe below the village of Umuluwe in Nigeria. In our travels in Ghana and Nigeria we found many villages like Umuluwe suffering the effects of failing biophysical 
factors, increased population pressure, and poor economic strategies resulting in extreme poverty and inequity.

We carried out two surveys of about 300 individuals in the small village of Umuluwe in Southeast Nigeria in 2001 and 2007. The village of Umuluwe is situated within the predominantly Christian southeast region of Nigeria, and is about 30 miles west of the regional capital of Owerri. Like most communities in Igboland, the Umuluwe is a close-knit village of about 3000 people. Except for interaction (through marriages, the church, and trade) with other neighboring villages, Umuluwe residents have limited contact with the outside world.

Umuluwe is representative of rural West African villages with difficult access from outside areas. The roads are quite a challenge for regular cars that, due to the pervasive poverty, are a luxury only very few can afford. There is no bus line, and people walk daily for hours to reach the nearby villages and the markets where their products are sold. Electricity was introduced only in the last seven years, due to the concerted effort of the community. However, because of undersupply and transmission problems, a chronic problem in Nigeria, power is on intermittently. There is no running water; the only water source is a small spring about one mile away from the center of the village. The soil has low fertility, there is no livestock and poor community members are unable to afford chemical fertilizers.

Per capita income in the village is about $\$ 150$ per annum, and the main sources of income are cash crops (palm trees and fruit), water and paving stone the same sources of income it has relied on for at least the past five decades. Farming is mainly for subsistence, although surpluses are sometimes produced and sold at the weekly markets in neighbouring villages. Proceeds from such surpluses are used to purchase items such as meat, milk, sugar and bread. The villagers also use the proceeds to pay community dues, school fees for their children, and healthcare costs.

With support from four research assistants who are residents of the village, socio-economic data were gathered from villagers who still reside in the village and those who migrated to Obigbo-a satellite town about 120 miles from the village. Data were collected on income, savings, investment, assets, debt, remittances, occupation, education, apprenticeship training, gender, age, marital status, etc. Many of the individuals were also interviewed face-to-face in order to obtain descriptive information. While $78 \%$ of those who migrated out of the village in search of better opportunities were men, only $22 \%$ were women, which may be due to cultural constraints on the mobility of women. This may also explain why the poverty rate tends to be higher amongst rural African women. While about $56 \%$ of non-migrant villagers earned less than $\$ 100$ per year, only $6 \%$ of the migrants earned less than this amount. Conversely, while $26 \%$ of migrants earned over $\$ 500$ per year, less than $6 \%$ of non-migrants earned this amount. Income distribution is skewed in favor of men, as 21 per cent of male migrants earned more than $\$ 5000$ a year while only 5 per cent of female migrants fell within this income bracket. Likewise, 5 per cent of non-migrant males earned over $\$ 5000$, while only 1 per cent of non-migrant women did so. 
We use the survey data to compute the poverty headcount index for the village. The poverty headcount index was calculated by finding the ratio of individuals who lived below the poverty line to all the individuals in the survey. The index is reported in Table 1 , and it reveals a very high poverty rate in the village, with $87 \%$ of all the respondents living below $\$ 1$ per day. An upward revision of the poverty line to $\$ 2$ per day increases the poverty rate amongst the respondents to an alarming 94\%; a rate rarely seen in most developing countries. A follow-up survey was undertaken in the same village in 2007 in order to investigate whether the poverty profile of the villagers had changed. Data on the poverty headcount index for 2007 are summarized in Table 2. As the table shows, poverty was still prevalent in 2007 , but at a lower rate compared to the 2001 levels.

Table 1: $\quad$ Headcount index for Umuluwe* and Africa** (\%): 2001 survey.

\begin{tabular}{|c|c|c|c|c|c|c|}
\hline & $\begin{array}{l}<\$ 1 \\
\text { per day }\end{array}$ & $\begin{array}{l}<\$ 2 \\
\text { per day }\end{array}$ & $\begin{array}{c}<\$ 1 \\
\text { per day } \\
\text { (Female) }\end{array}$ & $\begin{array}{c}<\$ 2 \\
\text { per day } \\
(\text { Female) }\end{array}$ & $\begin{array}{c}<\$ 1 \\
\text { per day } \\
(\text { Male) } \\
\end{array}$ & $\begin{array}{c}<\$ 2 \\
\text { per day } \\
\text { (Male) } \\
\end{array}$ \\
\hline $\begin{array}{l}\text { Non- } \\
\text { Migrant }\end{array}$ & 93.0 & 97.0 & 98.0 & 99.2 & 85.1 & 94.3 \\
\hline Migrant & 69.2 & 85.0 & 93.3 & 100.0 & 62.8 & 80.4 \\
\hline $\begin{array}{l}\text { Entire } \\
\text { Sample }\end{array}$ & 87.2 & 94.3 & 97.2 & 99.3 & 76.8 & 89.1 \\
\hline Africa-rural & 55.6 & & & & & \\
\hline Africa-urban & 43.0 & & & & & \\
\hline Africa & 52.3 & & & & & \\
\hline
\end{tabular}

* Own calculations (based on 2000 income)

** Ali and Nwabu (2002, p. 12)

Table 2: $\quad$ Headcount index for Umuluwe* (\%): 2007 survey.

\begin{tabular}{lcccccc}
\hline & $\begin{array}{c}<\$ 1 \\
\text { per } \\
\text { day }\end{array}$ & $\begin{array}{c}<\$ 2 \\
\text { per day }\end{array}$ & $\begin{array}{c}<\$ 1 \\
\text { per day } \\
\text { (Female) }\end{array}$ & $\begin{array}{c}<\$ 2 \\
\text { per day } \\
\text { (Female) }\end{array}$ & $\begin{array}{c}<\$ 1 \\
\text { per day } \\
\text { (Male) }\end{array}$ & $\begin{array}{c}<\$ 2 \\
\text { per day } \\
\text { (Male) }\end{array}$ \\
\hline $\begin{array}{l}\text { Non- } \\
\text { Migrant }\end{array}$ & 63.3 & 76.5 & 80.5 & 86.2 & 44.3 & 65.8 \\
$\begin{array}{l}\text { Migrant } \\
\text { Entire }\end{array}$ & 25.5 & 40.0 & 42.9 & 52.4 & 14.7 & 32.4 \\
Sample & 53.8 & 67.4 & 73.1 & 79.6 & 35.4 & 55.8 \\
\hline
\end{tabular}

*Own calculations (based on 2006 income)

Non-income measures of poverty such as protein consumption, number of meals per day, the proportion of income spent on food, type of fuel used for cooking, savings, debt, landownership, etc. may be better markers for how really poor the villagers are. Data on some non-income measures of poverty in 
Umuluwe are summarized in Table 3. Three of these measures point to the existence of chronic poverty in the village. About $75 \%$ of the respondents indicated that food accounted for the largest proportion of their expenditures, and only $33 \%$ consumes milk at least once weekly. About $24 \%$ indicated that they consume meat at least once every week. Over $60 \%$ of the respondents were in some type of debt. Over $90 \%$ used firewood as the main mode of cooking, while about half of the respondents owned no land.

Table 3: $\quad$ Non-income measures of poverty in Umuluwe, 2007.

\begin{tabular}{lccc}
\hline Indicator & $\begin{array}{c}\% \text { of } \\
\text { Sample }\end{array}$ & $\begin{array}{c}\% \\
\text { Men }\end{array}$ & $\begin{array}{c}\% \\
\text { Women }\end{array}$ \\
\hline Consumes Milk Weekly & 33 & 16 & 17 \\
Consumes Meat Weekly & 24 & 11 & 13 \\
Food as Most Important Expenditure & 75 & 36 & 39 \\
Firewood as Main Mode of Cooking & 91 & 42 & 49 \\
Owes Money & 62 & 27 & 36 \\
Has Savings & 55 & 34 & 21 \\
Owns Land & 53 & 37 & 16 \\
Owns Goats & 25 & 11 & 14 \\
Owns Chickens & 55 & 21 & 34 \\
\hline
\end{tabular}

Source: 2006 Village Survey

\section{Conclusions}

Although undernourishment is not a major problem in Ghana and Nigeria (only $10 \%$ of the population in these countries are hungry), Table 3 suggests that low protein consumption is widespread. Malnourishment is of greater concern in Ghana, where protein production and consumption are very low. Ghanaians survive on a surfeit of starchy vegetables such as cassava, yam, and coco yam to provide an adequate number of calories. Compared to other non-African countries and Nigeria, the average Ghanaian receives very little protein from either animal sources or pulse consumption. Moreover, the over reliance in Ghana on starchy vegetables has led to a vitamin A deficiency, as the vitamin is found primarily in green and orange fruits and vegetables. The deficiency can lead to stunted growth and blindness, especially in children [30]. Nigerians also consume very few calories from animal products compared to other non-African countries, but their level of pulse production is equal to more advanced countries in Latin America and Asia. Ghana imports nearly no supplemental protein, further increasing the deficiency [21]. In earlier times when forests were more abundant, bushmeat was a more readily available protein source [31]. Similarly, when water was more abundant and populations were smaller, fish provided sufficient protein to a greater proportion of the population. Neither forest nor aquatic ecosystems are now able to provide adequate nourishment to the rising population. While there is not a calorie crisis in either country at the present time, the prognosis for the future is not bright, if agricultural practices do not change in either country. 
Monocausal explanations have offered incomplete, and sometimes misleading, accounts of why agriculture in Africa has become unsustainable. Evidence from Ghana and Nigeria, however, suggests that agricultural sustainability has environmental, economic and equity ramifications. Specifically, the biophysical configuration of both countries has changed over the past five decades in ways that have grave implications for agricultural sustainability. Soil conditions, rainfall patterns, and forest use have all changed for the worst, making farmers in Ghana and Nigeria susceptible to declining productivity and poverty. Declining biophysical conditions in these countries have also been exacerbated by ineffective economic policies that encourage farmers to use their human and natural resources in unsustainable ways. Despite the increasing use of agricultural and arable land, Ghanaian and Nigerian rural dwellers are no better economically now than they were shortly after independence. Ghanaian and Nigerian farmers can no longer afford to continue on the path of unsustainability - a path that has not only been destructive of their natural environment, but also anathema to their economic and physiological well-being.

\section{References}

[1] Pretty, J. (1995). Regenerating Agriculture: Policies and Practices for Sustainability and Self-Reliance, London: Earthscan.

[2] Kuyek, D. (2002). "Intellectual Property Rights in African Agriculture: Implications for Small Farmers, Genetic Research Action International, August.

[3] Bryceson, D.F. (2004). "Agrarian Vista or Vortex: African Rural Livelihood Policies," Review of African Political Economy, 102: 617-629.

[4] Mortimore, M.J. and Adams, W.M. (2001). "Farmer Adaptation, Change and 'Crisis' in the Sahel," Global Environmental Change, 11: 49-57.

[5] Niemeijer, D. (1996). "The Dynamics of African Agricultural History: Is it Time for a New Development Paradigm?" Development and Change, 27: 87-110.

[6] McCusker, B. (2004). "Land Use and Cover Change as an Indicator of Transformation on Recently Distributed Farms in Limpopo Province, South Africa," Human Ecology, Vol. 32, No 1: 49-75.

[7] Lipton, M. (2007). "Can Small Farmers Survive, Prosper or be the Key Channel to Cut Mass Poverty?" Tips Monitor 38: 55-68.

[8] Ochieng, C. (2009). "Sustainable Agriculture in Africa: Towards a New Paradigm," Project Africa 2020.

[9] Hoben, A. (1995). "Paradigms and Politics: The Cultural Construction of Environmental Policy in Ethiopia," World Development, 23(6): 1007-1021.

[10] Altieri, M.A. (1995). Agroecology: The Science of Sustainable Agriculture, Boulder, CO: Westview Press.

[11] Pretty, J. (2004). "Can Sustainable Agriculture Feed Africa? New Evidence on Progress, Processes and Impact," Environment, Development and Sustainability, Vol.1, Nos 3-4: 253-274. 
[12] Haven, B. (2004). "OneWorld Guide: Ghana." Available Online: http://uk.oneworld.net/guides/ghana/development. Accessed 15 March 2009.

[13] Hess T.M., Stephens W., Maryah U.M. (1995). "Rainfall Trends in the North East Arid Zone of Nigeria 1965-1990," Agricultural and Forest Meteorology, 87: 87-97.

[14] All Africa News Source (2008), "Nigeria: The Desert is fast encroaching, but Why?" Available online: http://allafrica.com/stories /200803280949.html

[15] All Africa News Source (2008), "Ghana: Climate Change threat, is country taking it serious?" Available online: http://allafrica.com/stories /200803280949.html

[16] All Africa News Source (2008), “Africa: Invest in Food crops, continent told." Available online: http://allafrica.com/stories/200808290136.html

[17] USAID (2002). Nigeria Environmental Analysis Final Report. (USAID BIOFOR IQC No. LAG-I-00-99-00013-00).

[18] Safo A. (2002). “Bleak future as Ghana's forest cover diminishes," News from Africa. Available online: http://www.newsfromafrica.org /newsfromafrica/articles/art 7890.html.

[19] Anane, M. (2007). "Towards Sustainable Development in Ghana," Voices from Africa Number 6: Sustainable Development Part 2. UN-NonGovernmental Liaison Office. http://www.un-ngls.org/documents /publications.en/voices.africa/number6/vfa6.01.html

[20] FAO (2002). "Gateway to land and water information: Nigeria national report," Available online: http://www.fao.org/ag/agl/swlwpnr/reports /y_sf/z_ng/ng.htm .

[21] FAO (2004 a.) FAOSTAT on-line statistical service http://apps.fao.org

[22] FAO (2004 b.) Gateway to land and water information: Ghana national report. Available online: http://www.fao.org/ag/agl/swlwpnr/reports /y_sf/z_gh/gh.htm .

[23] FAO. (2000). Land Resources Potential and Constraints at Regional and Country levels, FAO, Rome.

[24] World Bank (2006). Nigeria Rapid Country Environmental Analysis.

[25] World Bank (2006). Ghana Country Environmental Analysis.

[26] FAO (2005). "Fertilizer use by crop in Ghana" Available online: http://www.fao.org/docrep/008/a0013e/a0013e05.htm\#TopOfPage .

[27] Cohen, R. (1981). Labour and Politics In Nigeria, London: Heinemann.

[28] Ayittey, G. (1999). Africa in Chaos, New York: St. Martins Press.

[29] Anyanwu, J.C. (1992). "President Babangida's Structural Adjustment Programme and Inflation in Nigeria," Journal of Social Development in Africa, 7(1): 5-24.

[30] Aguayo, V., Gamier, D., Baker, S. (2007). "Drops of Life," Published by UNICEF and Helen Keller International.

[31] Barth, E. (2008). "Catch Shares: Will a solution for fisheries work for Bushment?” Earth Trends. http://earthtrends.wri.org/updates/node/330 